\section{R.M. Gardner}

Department of Medical Informatics, University of Utah

Salt Lake City, Utah, USA

\title{
Research and Education
}

\section{University of Utah Medical Informatics Research and Training Program}

Science (M.Sc.) and Doctorate of Philosophy (Ph.D.) degrees. The Department is one of 12 National Library of Medicine (NLM) Medical Informatics training sites in the United States. The NLM Training Grant in Medical Informatics provides one of the rich areas of support for pre-doctoral as well as post-doctoral studentsat the University of Utah. The Veterans Administration provides some funding for Medical Informatics Trainees. Intermountain Health Care (IHC), the not-for-profit health care organization which owns the LDS Hospital also provides funding for training as well as providing ready access to their clinical facilities for Medical Informatics Trainees.

The present article updates earlier publications about the Medical Informatics Training program at the University of Utah. Warner's review of the Graduate Program in Medical Informatics at the University of Utah in 1994 [1] was part of a broader International Medical Informatics Association (IMIA) Working Group 1 review of six health/medical informatics programs [2]. Two more recent publications have also outlined the strengths of the Medical Informatics program at the University of Utah [3] and a historical perspective of the type of students have been educated at the University of Utah, and where they currently are employed in the academic as well as industrial workplace [4]. A detailed current description of the academic department is found on the World Wide Web (WWW) at the address indicated [5]. In addition to information about the Department there are instructions about how to apply to become a graduate student, details about faculty, faculty interests, research topics and course outlines and descriptions. Recently, the Abstracts from Master of Science Theses and Ph.D. Dissertations for students who have graduated since 1990 have also been made available at the same Web site [5].

In 1996, a major change in the number and type of students who were admitted to the academic program occurred. Prior to 1996, approximately 8 students were admitted each year, and those students were primarily engineering, computer scientists, and biologist. Since 1996, we have been admitting approximately 15 new students into the program each year, and about $70 \%$ of them have been physicians, typically with several years of residency training and several who were "Board" certified in medical fields such an Pediatrics, Internal Medicine, Surgery, Pathology.

Since the program's inception in 1964, there have been a total of 234 graduates. Of those 234, 138 have been awarded a MS degree and 96 have been awarded the PhD. Currently there are 64 graduate students enrolled. 


\section{Mission Statement Department of Medical Informatics}

The mission of the Department of Medical Informatics at the University of Utah is to improve health care outcomes through the use of information systems (including health, economic, and satisfaction results for consumers and providers) in the private and public sectors of the health care industry [5]. To accomplish this mission, the Department assumes three major responsibilities:

1. Educates medical professionals, medical informaticists, and the health care community in the field of medical informatics;

2. Promotes and conducts research to broaden medical informatics knowledge; and

3. To serve the health informatics professionals and consumers by participating in relevant professional societies, editorial boards, and continuing education programs, while maintaining medical informatics leadership in the community.

All of these responsibilities involve the active collaboration of faculty and students at the University of Utah, with the School of Medicine, University of Utah Medical Center, College of Nursing, Intermountain Health Care (IHC), LDS Hospital and other related hospitals and clinics, and the Department of Veterans Affairs, especially the Salt Lake VA Medical Center (VAMC).

A brief overview description of each of the five tracks is provided below. Table 1 outlines the Semester Credit Hours recommended for each student to complete a Master of Science Degree. Each student's actual course of study is established by a Faculty Advisory Committee. Each Masters student has a Chair of the Committee and two additional members. For the
Doctor of Philosophy student the Committee is composed of a Chair and four other members. The Chair of each of the Committees must be a member of the Medical Informatics Faculty.

\section{Overview of Departmental} Training Tracks

\section{Health Information Systems}

This track is designed to give students a clear understanding of the requirements, concepts, and methods to design, develop and evaluate health information systems (HIS). Emphasis is placed on implementation of clinical components of such systems and the integration of clinical systems with the more traditional administrative and financial health information systems. Students are provided both course work and practical project experience in working with an operational health

Table 1 - Spreadsheet of Course Offerings, Semester Credit Hours, and Faculty who teach the courses

\begin{tabular}{|c|c|c|c|c|c|c|c|c|c|c|c|c|}
\hline \multirow{3}{*}{ Course \# } & \multirow{2}{*}{$\begin{array}{l}\text { NOTE: Numbers in "middle" = Full Semester, } \\
\text { "left" numbers = the First Half Semester, } \\
\text { "right" numbers = theLast Half Semester, } \\
\text { * = every other year } \\
\text { Course Title } \\
\end{array}$} & \multirow{2}{*}{\begin{tabular}{r|} 
TRACK --> \\
Faculty Advisor-> \\
\end{tabular}} & \multicolumn{2}{|c|}{$\begin{array}{l}\text { \#1 Health } \\
\text { Information } \\
\text { Systems }\end{array}$} & \multicolumn{2}{|c|}{$\begin{array}{l}\text { \#2 Medical } \\
\text { Expert } \\
\text { Systems }\end{array}$} & \multicolumn{2}{|c|}{$\begin{array}{l}\text { \#3 Genetic } \\
\text { Informatics }\end{array}$} & \multicolumn{2}{|c|}{$\begin{array}{c}\text { \#4 Health Quality } \\
\text { Assurance }\end{array}$} & \multicolumn{2}{|c|}{$\begin{array}{l}\text { \#5 Medical } \\
\text { Imaging }\end{array}$} \\
\hline & & & Pincetl & & East & & Albright & & Weir/James & & Parker & \\
\hline & & \begin{tabular}{r|} 
Semester--> \\
\end{tabular} & Fall & Spr & Fall & Spr & Fall & Spr & Fall & Spr & Fall & Spr \\
\hline 5900 & Applications Programming & Sorenson & 3 & 3 & 3 & & 3 & & 3 & & 3 & \\
\hline 6000 & Medical Inform atics Core & Gardner & 6 & & 6 & & 6 & & 6 & & 6 & \\
\hline 6100 & Applied Statistics (every 2nd yr) & Horn & $2^{*}$ & & $2^{*}$ & & $2^{*}$ & & $2^{*}$ & & $2^{*}$ & \\
\hline 6110 & Research Design & Neuhausen & & 2 & & 2 & & 2 & & 2 & & 2 \\
\hline 6200 & Health Information Sys/Admin & Pincetl & & 3 & & 3 & & & & 3 & & 3 \\
\hline 6220 & MI Vocabulary \& Standards & Huff & & $3^{*}$ & & $3^{*}$ & & $3 *$ & & $3^{*}$ & & \\
\hline 6230 & Networks \& Communications & Bray/Sorenson & & $3^{*}$ & & & & & & & & $3^{*}$ \\
\hline 6300 & $\begin{array}{l}\text { Medical Decision-Making \& Knowledge } \\
\text { Engineering }\end{array}$ & East & & & & 4 & & & & & & \\
\hline 6350 & Mathematical Modeling (2 Spring) & Clark & & & & & & & & & & \\
\hline 6400 & Health - Quality of Care & Weir/James & & & & & & & & 4 & & \\
\hline 6450 & Primary Care/HIS & Shorr & & 2 & & & & & & & & \\
\hline 6460 & WWW Design (3 Spring) & Sorenson/Bray & & & & & & & & & & \\
\hline 6500 & Genetic Epidemiology & Neuhausen & & & & & & 2 & & & & \\
\hline 7000 & Graduate Seminar & Gardner & 1 & 1 & 1 & 1 & 1 & 1 & 1 & 1 & 1 & 1 \\
\hline 7010 & Journal Club (PhD Required) (2Fall/Spr) & Sorenson & & & & & & & & & & \\
\hline \multirow[t]{3}{*}{ IM7570 } & Research Ethics & Jacobsen & 1 & & 1 & & 1 & & 1 & & 1 & \\
\hline & $\begin{array}{r}\text { Total Required Hours---> } \\
\end{array}$ & & 13 & 14 & 13 & 13 & 13 & 8 & 13 & 13 & 13 & 9 \\
\hline & & As Outlined Total--> & & 27 & & 26 & & 21 & & 26 & & 22 \\
\hline \multirow[t]{4}{*}{6970} & MS Thesis Research--> & & & 7 & & 7 & & 7 & & 7 & & 7 \\
\hline & & As Outlined Total--> & & 34 & & 33 & & 28 & & 33 & & 29 \\
\hline & Minimum MS Total Required Hours & & & 30 & & 30 & & 30 & & 30 & & 30 \\
\hline & & & & & & & & & & & & \\
\hline RN6800 & $\begin{array}{l}\text { Computer Programming Course/s } \\
\text { Database Design (4) }\end{array}$ & & 4 & & 4 & & 4 & & 4 & & 4 & \\
\hline EDPS6300 & Statistics \& Research Design Ed Psych (3) & & 3 & & 3 & & 3 & & 3 & & 3 & \\
\hline & & & & & & & & & & & & \\
\hline
\end{tabular}

5900 -- is REQUIRED "OR" equivalent course or experience apply

6000 REQUIRED of ALL Medical Informatics Students

A000 REQUIRED of ALL Medical Informatics

Approximately 15 weeks of classes/semester
One semester hour $=1$ hour of classwork/wee

* $=$ Courses that are taught every other vear 
information system. For example, students develop and test informatics concepts and strategies using the HELP clinical computing systems located at LDS Hospital and Primary Children's Medical Center. In addition, clinical computing at the University of Utah Medical Center, Veterans Administration Medical Center, and any of the 20 other Intermountain Health Care (IHC) Hospitals and more than 15 clinics serve as laboratories where students can design, develop, implement, and evaluate applications for health information systems.

Based on the fact that many of our Medical Informatics graduates have become Chief Information Officers (CIO) [3], we have joined a consortium of University Departments in a multidisciplinary Health Services Administration (HSA) program. The HSA program is coordinated through the Office of the Vice President for Health Sciences, the Vice President for Academic Affairs, and the Governor Scott M. Matheson Center for Health Care Studies. The HSA program prepares students for administrative positions in policy and planning in both the public and private sectors of health care. The HSA program allows training of our students in the business school (MBA program, accounting, economics), as well as in public administration, public health, pharmacy, social work, nursing, health education, and anthropology. In the normal University curriculum, many of these graduate level courses would not be available to Medical Informatics students.

\section{Expert System}

This track emphasizes the application of techniques from expert systems research and artificial intelligence to problems in medicine. The students have access to expert systems implementations on stand-alone workstations as well as integrated health care enterprise information systems. Tools developed support both symbolic and mathematical techniques. Emphasis is placed on developing and evaluating practical tools that enhance the delivery of medical care and contribute to the objectives of medical education.

\section{Bioinformatics}

This track is designed to give students a thorough training in Bioinformatics, human genetics and statistics. The training is provided through practical work in the methods and software used in analysis of genetic data, and through training in a specific area of the student's choice. The current Genetic Epidemiology group has developed techniques for linking genealogical records with clinical health care records to provide insights into the familial and genetic linkages of diseases. This group found the first two Breast Cancer Genes and has recently found a Prostatic Cancer Gene. In addition to these forms of cancer, the group is working to provide linkages with a wide variety of human illnesses. A very active research group has provided a natural link for the Department of Medical Informatics to become even more active in Bioinformatics.

\section{Healthcare Quality}

This track emphasizes the application of expert systems and interactive learning modalities to facilitate institutional quality management and to maintain professional competence in the health care field. Students learn to apply computer skills to assist in the basic principles of: (a) quality management, including assessing and improving the effectiveness and efficiency of care; and (b) science information management, including identification of information needs, and retrieval and application of information to enhance the benefits of care.

Because of the Department's long standing affiliation with the LDS Hospital and Intermountain Health Care, the faculty and students have had a very close relationship with IHC's
Institute of Health Care Delivery Research. Dr. Brent C. James, a member of our faculty is the Director of this institute and has worked with our faculty and students to help them with Quality of Care projects.

\section{Medical Imaging}

This track emphasizes the applications of information processing in medical imaging. Students participate in the Medical Imaging Research Lab (MIRL) with students and faculty from several other departments. Research areas currently include digital X-ray imaging, magnetic resonance (MRI), and optical microscopy. A major activity of the imaging group is to provide high resolution MRI angiography of the brain and heart. These flow angiograms can be made without the injection of radiographic material. Mathematical methods for further improving images are an ongoing and exciting research topic for this talented group.

\section{Faculty}

The Department has a total of 37 faculty located at the University of Utah Health Sciences Center, LDS Hospital, Primary Children's Medical Center, Intermountain Health Care, in private industry, and at the University's Research Park. There are 12 Medical Doctors (MD), 17 who hold Doctorate Degrees (usually a Ph.D.), 3 who hold both an MD and Ph.D. Degree, and 5 who are Registered Nurses (RN) and also hold Doctorate Degrees. There are currently 14 who hold the rank of Professor, 14 who are Associate Professors, and 9 Assistant Professors.

By any measure that can be applied, the Department of Medical Informatics has a very outstanding faculty. In the current Faculty there are two members of the prestigious Institute of Medicine of the United States National Academy of Science (Homer R. Warner and Paul D. Clayton). Six members of the 
faculty have been elected to the American College of Medical Informatics (ACMI) (Homer R. Warner, Reed M. Gardner, T. Allan Pryor, Paul D. Clayton, Mark H. Skolnick, Stanley M. Huff, and R. Scott Evans) for their outstanding contributions to the field of Medical Informatics. Public service of the faculty in a variety of capacities in the field of Medical Informatics has also been remarkable. For example, two members of the faculty have served as President of the American Medical Informatics Association (AMIA) (Reed M. Gardner, Paul D. Clayton). Three members of the faculty have served on the Board of Directors of AMIA (Homer R. Warner, Reed M. Gardner, Paul D. Clayton). Stanley M. Huff currently serves as Chairman of the HL7 standards group. Homer R. Warner and T. Allan Pryor have served as Editors of Computers and Biomedical Research since the Journal's inception. Reed M. Gardner has served as Editor-in-Chief - International Journal of Clinical Monitoring and Computing. In addition, the time of service of the faculty has been remarkably stable, there are 3 Emeritus faculty (Homer R. Warner, John W. Williamson, T. Allan Pryor) and those with the rank of Professor have an average faculty service of over 25 years.

In 1994 Richard and Carol Fay donated \$1.0 Million to established the Fay Presidential Chair of Medical Informatics at the University of Utah in honor of Dr. Homer R. Warner. In 1999, the Fay's donated an additional $\$ 1.5$ Million to fund a second Presidential Chair in Medical Informatics as well as funding for graduate student fellowships. As far as the author knows, these Presidential Chairs are the only such endowed Chairs in Medical Informatics in the United States.

The University of Utah also has faculty in the School of Nursing involved in Nursing Informatics. Because of the key function nurses have in the health care delivery systems in the United States, the Department of Medical Informatics has established a close working relationship with the University of Utah College of Nursing Informatics program. Three Nursing Informatics faculty are Adjunct members of the Medical Informatics Department and five Medical Informatics faculty are Adjunct members of the College of Nursing Informatics program. This cooperative relationship allows for a collaborative sharing of faculty, courses, and students in research activities.

\section{Honors and Awards}

In 1998, in honor of the retirement of Homer R. Warner as Department Chairman, the Department established the Homer R. Warner Award. The cash award of $\$ 1,000$ is given each year to the most outstanding paper presented at the Fall American Medical Informatics Association meeting.

In 1983, the John D. Morgan Fellowship was established. This student fellowship, wasestablished by agenerous contribution by Dr. John D. Morgan, a former student and faculty member. The Fellowship is Awarded to an outstanding student completing their final year in a Master of Science or Doctor of Philosophy course of study.

Since 1997, the Bruce A. Houtchens Award, with a cash prize of $\$ 1,000$, has been presented to a University of Utah student who submits the most outstanding invited paper expressing their original ideas and research or development efforts in the area of health informatics or telemedicine. Students from the fields of Computer Science, Biomedical Engineering, Medical Informatics, Nursing and any other field of health care technology are invited to submit papers. Dr. Houtchens was a former member of the Faculty of Surgery at the University of Utah and the University of Texas at
Houston. He was completing his Master of Science Degree in Medical Informatics at the University of Utah at the time of his death. He and his wife, Dr. Maria Houtchens, now a Surgical Residentat Harvard University Hospital in Boston, were hiking in the hills north of the University when he suffered a fatal myocardial infarction. To honor Bruce's lifetime dedication to Medical Informatics and Telemedicine, Dr. Maria Houtchens established the Award in 1996.

\section{International Partnership in Health Informatics Education (IФE)}

In the Spring of 1999, an International Partnership between the University of Utah, the University of Minnesota in the United States along with the University of Amsterdam, in the Netherlands, and the University of Heidelberg and the University of Applied Sciences Heilbronn, in Germany - our European colleagues, was established. The purpose of this activity was to begin addressing the international scope of Health Informatics. The IФE partnership is designed to allow students and faculty from any of the Universities to visit, study and perform research at a partner University. Initially there have been exchanges of students to do shortterm (3 to 5 month) research projects. In addition, each year a "Master Class," with faculty and students from each of the institutions, meets and discusses current topics. This past summer (August 2000) a group of 20 students and 10 faculty met at an church abbey in the medieval town of Bad Wimpfen (near Heilbronn and Heidelberg) and later at the Medical Informatics Europe 2000 conference in Hannover, Germany. The theme discussed at Bad Wimpfen was "Regional Sharing and Standardization of Patient Data." Master teachers from the University of Utah, University of 
Amsterdam and the Technical University of Munich led the discussion. In addition, students made presentations on similar topics as well as on their own areas of research.

In addition to the formal international program described above, the Department has already trained 72 foreign students from Europe, Asia, South America, and the Middle East [3]. Most of these students have returned to their country of origin and are now providing Medical Informatics leadership in their home countries.

\section{Areas of Research and Development}

The Department of Medical Informatics at the University of Utah is internationally recognized for its contributions to computer applications in clinical care, medical education, and research. Although the earliest phases of the development of the research strengths of the Department were in understanding and developing physiological models, more recent activities have centered around operational clinical computing systems. Because of the breadth of current research, to give an overview of the Departmental activities, 10 research topic areas are outlined below. Each research topic area is provided with a paragraph or two describing the research and in addition a list of relevant references to provide more depth for those interested in a specific topic.

\section{Clinical Systems Applications}

The HELP (for Health Evaluation in Logical Processing) system has been the "centerpiece" of developments of the Department of Medical Informatics [6-8]. Initially installed at LDS Hospital, the system is now installed in several hospitals. The HELP system is a clinically oriented system which has become an integral part of the day-today operation at LDS Hospital. The system is unique in that it gathers patient data in a coded format so that the decision support engine can operate on the data and provide interpretations, alerts, reminders and drive patient care protocols. The HELP system has provided a platform for development of a wide variety of clinically applicable tools for improvement of medical care. Evaluations of the acceptance, use and value of clinical computing have been enhanced by availability of the HELP system. Faculty and graduate students in the Department have been the major contributors to the development and operation of the HELP system. Having ready access to the HELP system has provided a major laboratory of Medical Informatics research and development.

Developmental plans are underway to replace the HELP system at LDS Hospital, Intermountain Health Care (IHC, the parent company which owns and operates LDS Hospital and 21 other hospitals) with a Patient Care Management System. This Patient Care Management System is based on a centralized and lifetime patient data repository. The new system is being designed to have all the capabilities of the HELP system, but will also provide a lifetime record, contain data integrated from multiple hospitals and clinics, and will have extensive Data Warehouses to enhance clinical research. Whereas the HELP system was developed on main-frame technology, the new system is based on client-server technology and will make extensive use of Web data entry and review capabilities.

The University of Utah is also developing an electronic patient record and plans are underway to explore the legal, political, ethical and technical issues that will allow sharing of records between IHC and the University of Utah [9]. Other departmental systems such as the "Stork-bytes" labor and delivery system are being developed using client-server technology but with tight integration with the lifetime data repository.

\section{Critical Care Automation}

One of the first developmental areas to which the HELP clinical computing system was applied was to critical care and the Intensive Care Units (ICU) [7]. The ICU system has grown from acquisition of blood pressure and other physiological signals to a complete electronic patient record system. Computerized modules that support patient care in the ICU are: a) a nursing information system that computerizes nursing charting with nurse observations documentation, medications ordered and given, procedures performed, etc; b) computerized respiratory care charting; c) medication monitoring and charting; d) laboratory system integration; e) blood gas result integration and interpretation; $f$ ) hemodynamic monitoring; h) total parenteral nutrition (TPN) ordering and management; i) severity of illness scoring; j) Medical Information Bus (MIB) data acquisition; $\mathrm{k}$ ) infectious disease monitoring; 1) ventilator protocol monitoring; m) laboratory alerts; and n) computerized "rounds" display and reporting system $[10,11]$.

The Department with its faculty and graduate students have been active in development and evaluation of techniques to enhance patient care in the ICU. For example, development and testing of the IEEE 1073 Medical Information Bus (MIB) standard has enabled the automatic, accurate, timely and representative collection of data from critically ill patients [12-16].

\section{Clinical Decision-Support}

One of the most exciting and productive activities of the Department has been the development, testing, and evaluation of clinical decision-support systems using the HELP system [7,17]. Since the initial design and implementation of the HELP system, its developers have used the system to explore computerized interventions into the medical decision making process. These interventions imply a computer- 
directed interaction with physicians, nurses, and therapists involved in patient care. There are at least five different decision-support approaches that have been tested with the HELP system [17]. These include: a) Computerized interpretation of complex results, the Blood Gas interpretation program is an example [18]; b) alerting clinical staff to the important clinical data, Laboratory Alerting is an example [19]; c) critiquing of new orders and proposing changes to those orders, pharmacy and blood ordering are examples [20,21]; d) computerized protocols which recommend changes in patient therapy, two excellent examples are in daily operation on the HELP system - the antibiotic assistant [22], and the use of ventilator protocols [23]; and e) applications that summarize patient care data are useful to assist in therapeutic interventions, the ICU rounds report is an example [11].

\section{Evaluation of Clinical Computing Systems}

Because of the maturity and widespread use of the HELP clinical informationsystem, students, clinicians, andfaculty have been able to evaluate the use of the system [24]. In 1995 the Computerized Patient Record Institute (CPRI) awarded the first Nicholas E. Davies Computerized Patient Record Recognition to the developers of the HELP system. A wide variety of evaluation strategies have been developed, tested and applied to the HELP system. These include evaluation of physician and nurse acceptance of the expert system [25] and also assessment of the value and clinical applicability of the system [26, 27]. In the next segment examples of quality improvement are outlined.

\section{Using Computers to Improve Quality of Care \& Reduce Errors} in Medicine

With the recent publication of Institute of Medicine "To Err is Human" there has been an increased focus on using computerized expert systems like the HELP system to improve patient care [28]. Extensive research by the students, faculty and staff of the Medical Informatics Department have provided important examples where computerized systems can improve the quality of care and reduce errors [19, 27, 29-36]. Publication of the successful results of using computerized expert systems to improve the quality of care in some of the most prestigious clinical journals has givenmedical credibility to use of clinical computing.

\section{Vocabulary and Data Standards}

One of the most complex tasks facing the field of medical informatics is the establishment of vocabulary and data standards. Without standards to exchange data we are continually having to "invent" methods and vocabulary. Such an activity is frustrating and inefficient. At a time when the value of clinical information systems are becoming recognized, a major deterrent to widespread use and integration of multiple clinical sites is the lack of standards. Extensive work by Dr. Stanley M. Huff of our faculty along with his faculty colleagues and students have added important knowledge and operationally effective methods to the development of standards and vocabulary [37-43]. Work by other faculty members and colleagues in developing Arden Syntax for sharing decision-support knowledge has also been an important contribution [44-46].

\section{Genetic Epidemiology and Bioinformatics}

The Genetic Epidemiology group in the Department of Medical Informatics has been active for several decades in studying the predisposition to disease. Recently many genes that predispose to common diseases such as breast cancer, prostate cancer, and melanoma have been localized and cloned. The current initiative to map and sequence the human genome togetherwith rapidly advancing molecular biology techniques, ensure that this field will continue its rapid expansion. The group at Utah is now working toward development of a Bioinformatics track using recent funding from the National Library of Medicine.

The principal activity of the Genetic Epidemiology group at Utah has been to collect genealogical records and look for families at high risk of certain diseases. Then using modern genetic technologies, the group has found two breast cancer genes (BRCal and $\mathrm{BRCa} 2$ ) as well as genes for prostate cancer [47-58].

\section{Medical Imaging}

The medical imaging track of the Department is directed by Dennis L. Parker, recently recognized by the University of Utah at its 2000 Commencement as a Distinguished Research Professor. Dr. Parker and his colleagues are holders of three United States Patents in the field of Magnetic Resonance Imaging (MRI). The seminal work of this team headed by Dr. Parker developed the field of neuro and cardiac angiography using MRI so that blood flow in the brain and heart can be determined without use of contrast material [59-63]. Exciting opportunities for graduate students in bioengineering, medical informatics and physics are available with the Medical Imaging group.

\section{Public Policy Issues}

The field of Medical Informatics has several Public Policy issues that must be dealt with as the field matures. Perhaps the most important issues still under active consideration and discussion is Patient Privacy. Dr. Paul D. Clayton, while a faculty member at Columbia University, made a broad study for the Institute of Medicine of privacy and confidentiality issues in the United States. The results of the work are published in the book "For the 
Record: Protecting Electronic Health Information" [64, 65]. Current public policy and legislative activities in the United States use this excellent work as a model of how to protect patient records.

Clinical software systems are becoming ubiquitous. Although a growing literature documents how these systems can improve health care delivery, there is concern about patient safety using such systems. Dr. Randolph A. Miller and Dr. Reed M. Gardner formally addressed these issues when approached by the United States Food and Drug Administration (FDA) [66, 67]. Subsequently these investigators have set up Software Oversight Committees (SOC) in each of their institutions and are testing the validity of local oversight to minimize the impact of software errors in their institutions and those of two other similar institutions. Research results from using the "oversight" committees has proven positive. Several graduate students are involved in these studies.

\section{Natural Language Understanding}

Much of the patient's medical record is now in electronic form as "free text" from dictation and transcription services. Until recently, the text has only been available to clinical staff to "read" and ponder. However, there is a great need to have access to the data for computerized decisionsupport. Dr. Peter J. Haug, his students and medical colleagues have made excellent progress to unlocking this previously unavailable data for use in decision-support. To help resolve this problem, a medical language processing system called SymText, was developed by Spencer B. Koehler as a part of his Medical Informatics Doctoral Dissertation [68]. Subsequent use of the system has enhanced quality control, infectious disease monitoring, and allowed the development of protocols for pneumonia management in the emergency room [67-76]. With the recent advent of "voice recognition" systems and their use by radiologists, data from X-ray interpretations can be used for real-time computerized decision-support.

\section{The Future}

The future of Medical Informatics at the University of Utah is bright. With access to the HELP system at Intermountain Health Care, research investigations into computerized decision-support will continue. Perhaps even more exciting is the development of the HELP system replacement, the Patient Care Management System under way at IHC along with the Clinical Workstation now being used in multiple outpatient clinics. Both the Patient Care Management System and the Clinical Workstation operate from a highly coded and enterprise wide integrated database. From this centralized database we will be able to carry out Enterprise wide research into outcomes research at even a greater depth than in the past, because we will have not only hospital records, but all the major parts of the patient record. The database is being designed with a Web front end to allow for data entry and review at any location and by patients as well as care givers.

Combining the Enterprise, Lifetime view of clinical data with the genealogical and genetic data will challenge our Medical Informatics faculty, students and investigators for decades to come. There will be ethical, technical, political, and intellectual challenges greater than any that we have seen in the past. As I have often told my students, "I wish I could turn my biological clock back 30 years so I could see the exciting developments that will occur!"

Finally, will Medical Informatics become a real discipline? Dr. Homer R. Warner our Emeritus Chairman asked that question in 1995 [77]. Based on my 30 years of experience in the field of Medical Informatics at the University of Utah and based on the rate of change of medical knowledge acquisition, I can think of no more exciting field to be involved in. Certainly, Medical Informatics is already a real discipline!

\section{References}

1. Warner HR. Graduate program in Medical Informatics at the University of Utah. Methods Inf Med 1994;33(3):258-61.

2. Douglas JV, Leiner F. Summary of the General Discussion. IMIA Working Group 1 Conference. Methods Inf Med 1994;33(3):282-4.

3. Patton GA, Gardner RM. Medical informatics education: the University of Utah experience. J Am Med Inform Assoc 1999 Nov-Dec;6(6):457-65.

4. Gardner RM. Medical informatics at the University of Utah: applying research to real-life issues. MD Comput 1999 MayJun;16(3):29-32.

5. Web site for the Medical Informatics Graduate Program at the University of Utah: www.med.utah.edu/medinf September 2000.

6. Pryor TA, Gardner RM, Clayton PD, Warner HR. The HELP system. J Med Syst 1983 Apr;7(2):87-102.

7. Kuperman GJ, Gardner RM, Pryor TA. HELP: A Dynamic Hospital Information System. New York(NY): Springer-Verlag Inc; 1991.

8. Gardner RM, Pryor TA, Warner HR. The HELP hospital information system: update 1998. Int J Med Inf 1999 Jun;54(3):169-82.

9. Pincetl PS. Doing IT Right at the University of Utah. MD Comput 2000 NovDec;16(6):37-40.

10. Gardner RM, Sittig DF, Clemmer TP. Computer in the ICU: A match meant to be! In: Ayers SM, Grenvik A, Holbrook PR, Shoemaker WC, editors. Textbook of Critical Care Medicine. 3rd ed. Philadelphia (PA): W.B. Saunders; 1995. Chapter 196, p. $1757-70$.

11. Gardner RM, Shabot MM. PatientMonitoring Systems. In: Shortliffe EH, Perreault LE, editors. Medical Informatics: Computer Applications in Health Care, $2^{\text {nd }}$ ed. New York(NY): Springer-Verlag; 2000. Chapter 13, p. 443-84

12. Kennelly RJ, Gardner RM. Perspectives on development of IEEE 1073: The Medical Information Bus (MIB) Standard. Int J Clin 
Monit Comput 1997;14:143-9.

13. Dalto JS, Johnson KV, Gardner RM, Spuhler VJ, Egbert L. Medical Information Bus usage for automated IV pump data acquisition: Evaluation of use and nurse attitudes. Int J Clin Monit Comput 1997; 14:151-4.

14. Young WH, Gardner RM, East TD, Turner K. Computerized Ventilator Charting: Artifact Rejection and Data Reduction. Int J Clin Monit Comput 1997;14:165-76.

15. Gardner RM, Hawley WH, East TD, Oniki T, Young HFW. Real Time Data Acquisition: Recommendations for the Medical Information Bus (MIB). Int J Clin Monit Comput 1991;8:251-8.

16. Gardner RM, Hawley WH, East TD, Oniki T, Young HFW. Real time data acquisition: Experience with the Medical Information Bus (MIB) Proc Annu Symp Comput Appl Med Care (SCAMC) 1991;15:813-7.

17. Haug PJ, Gardner RM, Tate KE, Evans RS, East TD, Kuperman GJ, et al. Decision support in medicine: Examples from the HELP system. Comput Biomed Res 1994; 27:396-418.

18. Gardner RM, Cannon GH, Morris AH, Olsen KR, Price GA. Computerized blood gas interpretation and reporting system. IEEE Computer 1975;8(1):39-45.

19. Tate, KE, Gardner RM, Scherting K. Nurses, Pagers, and patient-specific Criteria: Three Keys to Improved Critical Value Reporting. Proc Annu Symp Comput Appl Med Care (SCAMC) 1995;19:164-8.

20. Hulse RK, Clark SJ, Jackson JC, Warner HR, Gardner RM. Computerized medication monitoring system. Am J Hosp Pharm 1976;33:1061-4.

21. Lepage EF, Gardner RM, Laub RM, Golubjatnikov OK. Improving Blood Transfusion Practice: Role of a Computerized Hospital Information System. Transfusion 1992;32:253-9.

22. Evans RS, Pestotnik SL, Classen DC, Clemmer TP, Weaver LK, Orme JF Jr, et al. A computer-assisted management program for antibiotics and other antiinfective agents. N Engl J Med 1998;338(4):232-8.

23. Morris AH. Developing and Implementing Computerized Protocols for Standardization of Clinical Decisions. Ann Intern Med 2000;132(5):373-83.

24. Grandia LC, Pryor TA, Willson DF, Gardner RM, Haug PJ, Huff SM, et al. Building a Computer-based Patient Record System in an Evolving Integrated Health System. In: Steen EB, editor. First Annual Nicholas E. Davies CPR Recognition Symposium Proceedings. April 4-6, 1995. p. $3-33$

25. Gardner RM, Lundsgaarde HP. Evaluation of physician and nurse acceptance of a computerized expert system. J Am Med Inform Assoc 1994;1:428-38.

26. Patton GA. Valuing Health Information Systems. Master of Science Thesis, Department of Medical Informatics, University of Utah. December 1999.

27. Evans RS, Pestotnik SL, Gardner RM Evaluation and Impact of Computer-based Drug Monitoring on the Quality and Cost of Drug Therapy. In: Prokosch U, Dudeck J, editors. Hospital Information systems: Design and Development Characteristics, Impact and Future Architectures. Amsterdam: Elsevier; 1995. p. 201-20

28. Richardson, WC (Chair), James BC (Committee) To Err is Human: Building a Safer Health System. Institute of Medicine, National Academy Press 1999.

29. James BC. Every defect a treasure: learning from adverse events in hospitals. Med J Aust 1997 May 5;166(9):484-7.

30. James BC. Implementing practice guidelines through clinical quality improvement. Front Health Serv Manage. 1993 Fall;10(1):3-37; p. 54-6.

31. Evans RS, Pestotnik SL, Classen DC, Burke JP. Evaluation of a computer-assisted antibiotic-dose monitor. Ann Pharmacother 1999 Oct;33(10):1026-31

32. Classen DC, Pestotnik SL, Evans RS, Lloyd JF, Burke JP. Adverse drug events in hospitalized patients. Excess length of stay, extra costs, and attributable mortality. JAMA 1997 Jan 22-29;277(4):301-6.

33. Pestotnik SL, Classen DC, Evans RS, Burke JP. Implementing antibiotic practice guidelines through computer-assisted decision support: clinical and financial outcomes. Ann Intern Med 1996 May 15;124(10):884-90.

34. Evans RS, Classen DC, Pestotnik SL, Clemmer TP, Weaver LK, Burke JP. A decision support tool for antibiotic therapy. Proc Annu Symp Comput Appl Med Care 1995;651-5.

35. Evans RS, Classen DC, Pestotnik SL, Lundsgaarde HP, Burke JP. Improving empiric antibiotic selection using computer decision support. Arch Intern Med 1994 Apr 25;154(8):878-84.

36. Evans RS, Pestotnik SL, Classen DC, Horn SD, Bass SB, Burke JP. Preventing adverse drug events in hospitalized patients. Ann Pharmacother 1994 Apr;28(4):523-7.

37. Huff SM, Rocha RA, McDonald CJ, et al. Development of the Logical Observation Identifier Names and Codes (LOINC) Vocabulary. J Am Med Inform Assoc 1998 May-Jun;5(3):276-92.

38. Huff SM, Bidgood WD Jr, Cimino JJ, Hammond WE. A proposal for incorporating health level seven (HL7) vocabulary in the UMLS Metathesaurus. Proc AMIA
Symp 1998;800-4.

39. Huff SM. Clinical data exchange standards and vocabularies for messages. Proc AMIA Symp 1998;62-7.

40. Rocha RA, Huff SM, Haug PJ, Evans DA, Bray BE. Evaluation of a semantic data model for chest radiology: application of a new methodology. Methods Inf Med 1998 Nov;37(4-5):477-90

41. Huff SM, Rocha RA, Solbrig HR, et al. Linking a medical vocabulary to a clinical data model using Abstract Syntax Notation 1. Methods Inf Med 1998 Nov;37(4-5):440-52.

42. Patterson R, Huff SM. The decline and fall of Esperanto: lessons for standards committees. J Am Med Inform Assoc 1999 Nov-Dec;6(6):444-6.

43. Bakken S, Campbell KE, Cimino JJ, Huff SM, Hammond WE. Toward vocabulary domain specifications for Health Level 7coded data elements. J Am Med Inform Assoc 2000 Jul-Aug;7(4):333-42.

44. Pryor TA, Hripcsak G. The Arden syntax for medical logic modules. Int J Clin Monit Comput 1993 Nov;10(4):215-24.

45. Pryor TA, Hripcsak G. Sharing MLM's: an experiment between Columbia-Presbyterian and LDS Hospital. Proc Annu Symp Comput Appl Med Care 1993;399-403.

46. Hripcsak G, Ludemann P, Pryor TA, Wigertz OB, Clayton PD. Rationale for the Arden Syntax. Comput Biomed Res 1994 Aug;27(4):291-324.

47. Lewis C, Book L, Black J, Sawitzke A, Cannon-Albright L, Zone J, et al. Celiac disease and human leukocyte antigen genotype: accuracy of diagnosis in selfdiagnosed individuals, dosage effect, and sibling risk. J Pediatr Gastroenterol Nutr $2000 \mathrm{Jul} ; 31(1): 22-7$.

48. Bansal A, Critchfield GC, Frank TS, Reid JE, Thomas A, Deffenbaugh AM, et al. The predictive value of BRCA 1 and BRCA2 mutation testing. Genet Test 2000;4(1):45-8.

49. Skolnick MH. The future of DNA diagnostics. Dis Markers 1999 Oct;15 (1-3):106-7.

50. Thomas A, Cannon-Albright L, Bansal A, Skolnick MH. Familial Associations between Cancer Sites. Comput Biomed Res 1999 Dec;32(6):517-29.

51. Neuhausen SL, Farnham JM, Kort E, Tavtigian SV, Skolnick MH, CannonAlbright LA. Prostate cancer susceptibility locus HPC1 in Utah high-risk pedigrees. Hum Mol Genet 1999 Dec;8(13):2437-42.

52. Frank TS, Skolnick MH. Testing for hereditary cancer risk: Pandora or Prometheus? J Clin Endocrinol Metab 1999 Jun;84(6):1882-5.

53. Skolnick MH, Frank T, Shattuck-Eidens 
D, Tavtigian S. Genetic susceptibility to breast and ovarian cancer. Pathol Biol(Paris) 1997 Mar;45(3):245-9.

54. Neuhausen SL, Godwin AK, GershoniBaruch R, Schubert E, Garber J, StoppaLyonnet D, et al. Haplotype and phenotype analysis of nine recurrent BRCA2 mutations in 111 families: results of an international study. Am J Hum Genet 1998;62: 1381-8.

55. Swensen J, Hoffman M, Skolnick MH, Neuhausen SL. Identification of a $14 \mathrm{~kb}$ deletion involving the promoter region of BRCA1 in a breast cancer family. Hum Mol Genet 1997 Sep;6(9):1513-7.

56. Neuhausen SL, Ostrander EA. Mutation testing of early-onset breast cancer genes BRCA1 and BRCA2. Genet Test 1997; 1(2):75-83.

57. Neuhausen SL, Skolnick MH, CannonAlbright L. Familial prostate cancer studies in Utah. Br J Urol 1997 Mar;79(Suppl 1):15-20.

58. Durocher F, Shattuck-Eidens D, McClure M, Labrie F, Skolnick MH, Goldgar DE, et al. Comparison of BRCA1 polymorphisms, rare sequence variants and/or missense mutations in unaffected and breast/ovarian cancer populations. Hum Mol Genet 1996 Jun;5(6):835-42.

59. Chapman BE, Goodrich CK, Alexander AL, Blatter DD, Parker DL. Evaluation of Measures of Technical Image Quality for Intracranial Magnetic Resonance Angiography. Comput Biomed Res 1999 Dec;32(6):530-56.

60. Parker DL, Roberts JA, Alexander AL, Goodrich KC, Tsuruda J. Magnetic resonance angiography with sliding interleaved projection reconstruction (SLIPR) acquisition. J Magn Reson Imaging 1999 Oct;10(4):569-75.

61. Parker DL, Goodrich KC, Alexander AL, Buswell HR, Blatter DD, Tsuruda JS. Optimized visualization of vessels in contrast enhanced intracranial MR angiography. Magn Reson Med 1998
Dec;40(6):873-82.

62. Parker DL, Tsuruda JS, Goodrich KC, Alexander AL, Buswell HR. Contrastenhanced magnetic resonance angiography of cerebral arteries. A review. Invest Radiol 1998 Sep;33(9):560-72.

63. Du YP, Parker DL. Optimal design of gradient coils in MR imaging: optimizing coil performance versus minimizing cost functions. Magn Reson Med 1998 Sep;40(3):500-3.

64. Clayton PD, Chair. For the Record: Protecting Electronic Health Information. 1997 National Academy Press.

65. Clayton PD. Improving the privacy and security of electronic health information. Acad Med.1997 Jun;72(6):522-3.

66. Miller RA, Gardner RM. Summary recommendations for responsible monitoring and regulation of clinical software systems. Ann Intern Med 1997 Nov 1;127(9):842-5.

67. MillerRA, Gardner RM. Recommendations for responsible monitoring and regulation of clinical software systems. J Am Med Inform Assoc 1997 Nov-Dec;4(6):442-57.

68. Koehler SB. SymText: A natural understanding system for encoding free text medical data. Doctoral Dissertation, University of Utah Department of Medical Informatics. Summer 1997.

69. Gundersen ML, Haug PJ, Pryor TA, van Bree R, Koehler S, Bauer K, et al. Development and evaluation of a computerized admission diagnoses encoding system. Comput Biomed Res 1996 Oct;29(5):351-72.

70. Haug PJ, Christensen L, Gundersen M, Clemons B, Koehler S, Bauer K. A natural language parsing system for encoding admitting diagnoses. Proc AMIA Annu Fall Symp 1997;814-8.

71. Chapman WW, Haug PJ. Comparing expert systems for identifying chest $\mathrm{x}$-ray reports that support pneumonia. Proc AMIA Symp 1999;(1-2):216-20.

72. Aronsky D, Haug PJ. Diagnosing community-acquired pneumonia with a Bayesian network. Proc AMIA Symp 1998;:632-6.

73. Aronsky D, Haug PJ. An integrated decision support system for diagnosing and managing patients with communityacquired pneumonia. Proc AMIA Symp 1999;(1-2):197-201.

74. Fiszman M, Chapman WW, Evans SR, Haug PJ. Automatic identification of pneumonia related concepts on chest $x$-ray reports. Proc AMIA Symp. 1999;(1-2):67-71.

75. Fiszman M, Haug PJ, Frederick PR. Automatic extraction of PIOPED interpretations from ventilation/perfusion lung scan reports. Proc AMIA Symp 1998;860-4.

76. Aronsky D, Haug PJ. Assessing the quality of clinical data in a computer-based record for calculating the pneumonia severity index. J Am Med Inform Assoc 2000; $7(1): 55-65$

77. Warner HR. Medical Informatics: A Real Discipline? J Am Med Informatics Assoc 1995;2:207-14

Address of the author:

Reed M. Gardner, PhD

Professor and Chairman

Department of Medical Informatics, University of Utah

Co-Director of Medical Informatics, LDS Hospital

University of Utah

School of Medicine, Room AB193

50 North Medical Drive

Salt Lake City, Utah, USA

E-mail: Reed.Gardner@hsc.utah.edu 